\title{
Hubungan Tingkat Pengetahuan Tentang Antibiotik dengan Sikap dan Tindakan Penggunaan Antibiotik Tanpa Resep pada Mahasiswa/i Universitas HKBP Nommensen Medan
}

\author{
Mega Oktavia Sianturi ${ }^{1}$, Henny Erina Saurmauli Ompusunggu ${ }^{2}$, Djohan $^{3}$ \\ 1,2,3 Fakultas Kedokteran Universitas HKBP Nommensen, Medan \\ Email : ompusunggu.henny@gmail.com
}

\begin{abstract}
Abstrak
Pendahuluan: Antibiotik merupakan obat yang digunakan untuk mencegah dan mengobati infeksi yang disebabkan oleh bakteri. Penggunaan antibiotik yang tidak tepat dapat menimbulkan beragam masalah, seperti resistensi bakteri terhadap antibiotik. Salah satu penyebab terjadinya resistensi bakteri terhadap antibiotik adalah penggunaan antibiotik yang tidak rasional tanpa resep. Tujuan: untuk mengetahui hubungan tingkat pengetahuan tentang antibiotik dengan sikap dan tindakan penggunaan antibiotik tanpa resep pada mahasiswa/i Universitas HKBP Nommensen. Metode: Sebanyak 210 orang mahasiswa/i aktif Universitas HKBP Nommensen diikutsertakan sebagai responden pada penelitian analitik cross sectional ini. Tingkat pengetahuan, sikap dan tindakan responden diukur dengan menggunakan kuesioner. Uji Chi Square digunakan untuk menganalisis apakah dijumpai hubungan antara pengetahuan dan sikap dengan tindakan responden. Hasil: Tidak terdapat hubungan yang bermakna antara tingkat pengetahuan tentang antibiotik dengan sikap dan tindakan penggunaan antibiotik tanpa resep pada Mahasiswa/i Universitas HKBP Nommensen Medan ( $p$ > 0,05). Kesimpulan: Pengetahuan bukan faktor dominan yang mempengaruhi sikap dan tindakan seseorang dalam penggunaan antibiotik tanpa resep.
\end{abstract}

Katakunci : Pengetahuan, sikap, tindakan, antibiotik, tanpa resep

\begin{abstract}
Introduction: Antibiotics are drugs that are used to prevent and treat infections caused by bacteria. Inappropriate use of antibiotics can cause various problems, such as bacterial resistance to antibiotics. One of the causes of bacterial resistance to antibiotics is the irrational in non prescription use of antibiotics. Aims: to determine the association of knowledge level about antibiotics with attitude and action level in non prescription use of antibiotics in Universitas HKBP Nommensen students. Method: There was 210 active students of Universitas HKBP Nommensen were included as respondents in this cross sectional study. The level of knowledge, attitudes and actions of respondents were measured using a questionnaire. Chi Square test was used to analyzed the association of knowledge with attitude and action of respondents. Result: There was no significant association of knowledge level about antibiotics with attitude and action level in non prescription use of antibiotics in Universitas HKBP Nommensen students ( $p>0,005)$. Conclusion: Knowledge is not a dominant factor influencing both attitude and action in non prescription use of antibiotics.
\end{abstract}

Keyword s: Knowledge, attitude, actions, antibiotics, non prescription 


\section{Pendahuluan}

Antibiotik merupakan obat yang berfungsi untuk mencegah dan mengobati infeksi yang disebabkan oleh bakteri. Sebagai salah satu jenis obat umum, antibiotik banyak beredar di masyarakat. ${ }^{1}$ Hanya saja, penggunaan antibiotik yang tidak tepat menimbulkan beragam masalah. Hal ini merupakan ancaman global bagi kesehatan terutama dalam hal resistensi antibiotik.

Resistensi antibiotik terjadi karena penggunaan yang meluas dan tidak rasional, beberapa faktor yang mendukung terjadinya resistensi adalah penggunaannya yang terlalu singkat, dosis yang terlalu rendah, diagnosis awal yang salah, indikasi yang kurang tepat, misalnya infeksi virus, dan penggunaan antibiotik tanpa resep. ${ }^{2,3}$ Dari beberapa survei yang dilakukan alasan masyarakat membeli antibiotik tanpa resep antara lain, $87,45 \%$ karena sudah pernah menggunakan antibiotik sebelumnya dan sisanya $12,55 \%$ karena alasan lainnya. ${ }^{4}$ Pada penelitian yang lain didapati bahwa $89,89 \%$ masyarakat beranggapan bila menderita penyakit yang sama maka penggunaan antibiotik berulang dapat dilakukan. ${ }^{5}$ Sedangkan penelitian yang dilakukan di kota Kediri didapati 75,26\% masyarakat membeli antibiotik tanpa resep karena pengobatan sebelumnya memberikan hasil yang baik. Dan pada penelitian yang dilakuakan pada ibu-ibu didapati alasan penggunaan antibiotik tanpa resep antara lain $37,28 \%$ mengetahui jenis antibiotik yang digunakan, $23,15 \%$ karena biaya yang murah, $11,98 \%$ menggunakan obat sisa dari pengobatan dokter sebelumnya, 24,34\% disarankan oleh teman/keluarga dan 3,25\% karena tidak tahu. ${ }^{6}$

Menurut World Health Organization (WHO) pembelian antibiotik tanpa resep $64 \%$ terjadi di negara yang berada di Asia Tenggara. Penggunaan antibiotik tanpa resep terjadi di beberapa negara, seperti di Korea Selatan perilaku penggunaan antibiotik tanpa resep dipengaruhi oleh umur dan pengetahuan konsumen tentang antibiotik. Pada responden berumur 18-39 tahun pengetahuan tentang penggunaan antibiotik lebih rendah dari responden berumur 40-59 tahun, dan responden yang telah lulus perguruan tinggi 2,39 kali lebih mengerti tentang penggunaan antibiotik. ${ }^{7}$ Survei di Palestina menunjukkan penggunaan antibiotik tanpa resep dipengaruh oleh faktor ekonomi. Dimana masyarakat yang memiliki tingkat perekonomian menengah keatas sikap dan perilaku penggunaan antibiotik juga lebih baik. $^{8}$

Di Indonesia $86,10 \%$ masyarakat mendapatkan antibiotik tanpa resep. Berdasarkan hasil penelitian yang dilakukan Yusuf Sholihan tahun 2015 di Kecamatan Jebres Kota Surakarta dari 276 responden, terdapat $64,86 \%$ pernah membeli antibiotik tanpa resep. Hasil penelitian menunjukkan bahwa terdapat $36,96 \%$ memiliki tingkat pengetahuan yang rendah, 43,48\% memiliki tingkat pengetahuan sedang dan $19,57 \%$ memiliki tingkat pengetahuan yang tinggi tentang antibiotik. ${ }^{9}$ Penelitian Fatmawati dan Irma tahun 2014 yang dilakukan pada mahasiswa kesehatan dan non kesehatan di Universitas Muhammadiyah Surakarta menunjukkan bahwa pengetahuan, sikap dan perilaku responden baik dan cukup dalam hal penggunaan antibiotik. ${ }^{10}$

Pada penelitian yang dilakukan oleh Theodorus Garry Putra Gan, tahun 2017, pada mahasiswa Universitas Respati Yogyakarta didapati hasil semakin tinggi pengetahuan seseorang terkait antibiotik maka semakin baik sikap dan tindakan untuk tidak menggunakan antibiotik tanpa resep. Berbeda dengan hasil penelitian yang dilakukan oleh Hasnal Laily Yarza dkk, tahun 2015, dimana didapati hasil tidak terdapat hubungan yang bermakna antara tingkat pengetahuan dengan penggunaan antibiotik tanpa resep. ${ }^{11,12}$

Mahasiswa/i merupakan salah satu komponen masyarakat yang memiliki 
pengetahuan tinggi yang diharapkan dapat memiliki pengetahuan yang baik tentang antibiotik dan dapat mengedukasi keluarga, teman dan masyarakat untuk tidak menggunakan antibiotik tanpa resep. Oleh karena itu peneliti tertarik untuk meneliti hubungan tingkat pengetahuan tentang antibiotik dengan sikap dan tindakan penggunaan antibiotik tanpa resep pada mahasiswa/i Universitas HKBP Nommensen.

\section{Metode Penelitian}

Penelitian ini dilaksanakan di Unversitas HKBP Nommensen Medan pada bulan Oktober - Desember 2019. Populasi penelitian ini adalah seluruh mahasiswa/i Universitas Universitas HKBP Nommensen Medan yang sesuai dengan syarat inklusi yaitu hadir pada saat penelitian ini dilakukan. Melalui rumus analitik kategorik tidak berpasangan diperoleh sampel sebanyak 210 responden. Dengan menggunakan teknik Qouta Sampling, dimana jumlah sampel dibagi dalam proporsi jumlah yang sama pada setiap fakultas di Universitas HKBP Nommensen yaitu Fakultas Hukum, Ekonomi, Teknik, Seni dan Bahasa, Pertanian, Peternakan, llmu sosial dan ilmu politik, diperoleh sampel tiap fakultas sebesar 30 sampel.

Analisis data menggunakan analisis univariat yaitu untuk memperoleh gambaran distribusi ataupun frekuensi disajikan dalam bentuk tabel dan analisis bivariat untuk mengetahui hubungan antara kedua variable pada penelitian, dengan menggunakan uji Chi Square.

\section{HASIL}

Karakteristik responden penelitian dapat dilihat di Tabel 1.

Tabel 1. KaRakteristik Responden Penelitian

\begin{tabular}{lcc}
\hline \multicolumn{1}{c}{ Karakteristik } & $\mathbf{N}$ & $(\boldsymbol{\%})$ \\
\hline $\begin{array}{l}\text { Jenis Kelamin } \\
\text { - Laki-laki }\end{array}$ & 113 & $(53,8)$
\end{tabular}

\begin{tabular}{lcc} 
- Perempuan & 97 & $(46,2)$ \\
Semester & & \\
-3 (Tiga) & 91 & $(43,3)$ \\
-4 (Empat) & 119 & $(56,7)$ \\
\hline
\end{tabular}

Distribusi responden berdasarkan pengetahuan, sikap dan tindakan responden dapat dilihat di Tabel 2.

TABEL 2. DistribuSI RESPONDEN BERDASARKAN Pengetahuan, SikaP, Tindakan

\begin{tabular}{lcc}
\hline Univariat & $\mathbf{N}$ & $\mathbf{( \% )}$ \\
\hline Pengetahuan & & \\
- Baik & 165 & $(78,6)$ \\
- Kurang & 45 & $(21,4)$ \\
Sikap & & \\
- Baik & 174 & $(82,9)$ \\
- Kurang & 36 & $(17,1)$ \\
Tindakan & & \\
- Baik & 120 & $(57,1)$ \\
- Kurang & 90 & $(42,9)$ \\
\hline
\end{tabular}

Hubungan tingkat pengetahuan tentang antibiotik dengan sikap dan tindakan penggunaan antibiotik tanpa resep pada mahasiswa/i Universitas HKBP Nommensen Medan dapat dilihat di Tabel 3 dan Tabel 4.

Tabel 3. Hubungan Tingkat Pengetahuan TENTANG ANTIBIOTIK DENGAN SIKAP PENGGUNAAN ANTIBIOTIK TANPa RESEP PADA MAHASISWa/I UNIVERSITAS HKBP NOMMENSEN MEDAN

\begin{tabular}{lccc}
\hline \multirow{2}{*}{ Pengetahuan } & \multicolumn{2}{c}{ Sikap } & \multirow{2}{*}{$\boldsymbol{p}$} \\
\cline { 2 - 3 } & Kurang & Baik & \\
\hline Baik & $\mathbf{N}$ & $\mathbf{N}$ & \\
\multirow{2}{*}{ Kurang } & 24 & 141 & \\
& $(14,5 \%)$ & $(85,5 \%)$ & 0,056 \\
& 12 & 33 & \\
\hline
\end{tabular}

Tabel 4. Hubungan Tingkat Pengetahuan TENTANG ANTIBIOTIK DENGAN TINDAKAN Penggunaan antibiotik TanPa Resep pada MAHASISWA/I UNIVERSITAS HKBP NOMMENSEN MEDAN

\begin{tabular}{lccc}
\hline \multirow{2}{*}{ Pengetahuan } & \multicolumn{2}{c}{ Tindakan } & $\boldsymbol{p}$ \\
\cline { 2 - 3 } & Kurang & Baik & \\
\hline Baik & $\mathbf{N}$ & $\mathbf{N}$ & \\
\multirow{4}{*}{ Kurang } & 73 & 92 & \\
& $(44,2 \%)$ & $(55,8 \%)$ & 0,437 \\
& 17 & 28 & \\
\hline
\end{tabular}

Hasil penelitian ini menunjukkan bahwa 
tidak terdapat hubungan yang signifikan antara tingkat pengetahuan tentang antibiotik dengan sikap dan tindakan penggunaan antibiotik tanpa resep $(\mathrm{p}>0,05)$.

\section{Pembahasan}

Dari hasil penelitian pada tabel 2 diketahui bahwa tingkat pengetahuan mahasiswa/i tentang penggunaan antibiotik tanpa resep paling banyak pada kategori baik. Hasil penelitian ini sesuai dengan penelitian Hasnal Laily Universitas Andalas tahun 2015 pada masyarakat di Kampung Seberang Pebayan RW IV Kelurahan Batang Arau Padang Selatan dimana mayoritas responden memiliki tingkat pengetahuan yang baik. Berdasarkan sikap mahasiswa tentang penggunaan antibiotik tanpa resep menunjukkan bahwa mayoritas mahasiswa/i memiliki sikap yang baik. Hasil penelitian ini sesuai dengan penelitian Hasnal Laily Universitas Andalas tahun 2015 pada masyarakat di Kampung Seberang Pebayan RW IV Kelurahan Batang Arau Padang Selatan dimana mayoritas responden memiliki sikap yang baik dalam penggunaan antibiotik. Hasil penelitian ini juga sejalan dengan penelitian yang dilakukan oleh Arilinia Pratiwi Universitas Lampung pada tahun 2018 pada masyarakat Sekampung Kabupaten Lampung Timur dimana didapati mayoritas responden memiliki sikap yang baik. Berdasarkan sikap, hasil penelitian ini menunjukkan mayoritas mahasiswa memiliki tindakan yang baik. Hasil penelitian ini sejalan dengan penelitian yang dilakukan oleh Theodorus Garry Putra Ganna Universitas Sanata Dharma Yogyakarta pada tahun 2017 pada mahasiswa Ilmu Kesehatan Universitas Respati Yogyakarta dimana didapati mayoritas responden memiliki tindakan yang baik dalam hal penggunaan antibiotik tanpa resep. Penelitian ini menunjukkan bahwa tingkat pengetahuan tentang antibiotik tidak berhubungan dengan sikap dan tindakan penggunaan antibiotik tanpa resep $(p>0,05)$. Penelitian ini tidak sejalan dengan penelitian Theodorus Garry
Putra Gana yang membuktikan adanya hubungan pengetahuan tentang antibiotik dengan sikap dan tindakan penggunaan antibiotik tanpa resep.

Secara teori sikap dan tindakan dipengaruhi oleh tingkat pengetahuan individu tentang suatu hal, akan tetapi masih ada beberapa faktor yang dapat mempengaruhi sikap dan tindakan seperti kepercayaan, pengalaman dan nilai-nilai yang berlaku dalam masyarakat. Sikap dan tindakan mahasiswa/i juga sangat dipengaruhi oleh faktor lingkungan sehingga sering terjadi pada seseorang dengan tingkat pengetahuan yang baik sering terikut-ikut untuk mengambil sikap dan tindakan yang tidak sesuai dengan pengaruh teman ataupun pengalaman teman sekitarnya. Selain itu kemajuan zaman yang semakin memudahkan individu untuk mencari informasi juga menjadi faktor yang mempengaruhi tingkat pengetahuan mahasiswa/i. Hal tersebut yang menjadi penjelasan mengapa pada penelitian ini tingkat pengetahuan tidak memiliki hubungan dengan sikap dan tindakan. ${ }^{13,14}$ Kenyataan yang ditemukan dilapangan saat penelitian ini berlangsung adalah terdapat mahasiswa/i yang memiliki tingkat pengetahuan baik tetapi memiliki sikap dan tindakan yang kurang dalam penggunaan antibiotik tanpa resep. Seperti yang sudah dijelaskan sebelumnya bahwa sikap dan tindakan seseorang dapat dipengaruhi oleh faktor lingkungan. ${ }^{15}$

\section{KeSimpulan Dan SARan}

Tidak terdapat hubungan yang bermakna antara tingkat pengetahuan tentang antibiotik dengan sikap dan tindakan penggunaan antibiotik tanpa resep pada Mahasiswa/i Universitas HKBP Nommensen Medan $(\mathrm{p}>0,05)$. Untuk penelitian selanjutnya diharapkan dapat meneliti faktor-faktor lain yang juga mempengaruhi sikap dan tindakan seseorang dalam penggunaan obat tanpa resep. 
January 2021

\section{Daftar Pustaka}

[1] Kesehatan K. Pasien Cerdas, Bijak Gunakan Antibiotik. 2016.hal:1-4 .

[2] Baroroh HN U dkk. Peningkatan Pengetahuan Masyarakat Melalui Edukasi Tentang Penggunaan Antibiotik Bijak dan Rasional. Pharmacology. 2018;1(1) hal : 8-15.

[3] Utami Eka Rahayu. Antibotika Resisten dan Rasionalitas Terapi. El-Hayah. 2011.hal: 1-8.

[4] Fernandez BAM. Studi Pengunaan Antibiotik Tanpa Resep di Kabupaten Manggarai NTT. 2013;2(2)hal:14.

[5] Ihsan, Kartina dkk. Studi Penggunaan Antibiotik Non Resep di Apotek Komunitas Kota Kendari. Ilmu Farmakol. 2016;2(13).hal:84-272.

[6] Mufidatum N, Pratiwi DW dkk. Profil Penggunaan dan Pengetahuan Antibiotik pada Ibu-ibu. Farm Komunitas. 2016;1(3).hal:7-12.

[7] Kim so sun, Kim eun jung, dkk. Public Knowledge and Attitudes Regarding Antibiotik Use In South Korea. Korea Acad Nurse. 2011;6(41).hal:1-3.

[8] R K, Malou N. Antibiotic Resistance in Palestina [Internet]. BMJ. 2018. Available from: http://dx.doi.org/doi10.1136/bmj.k4273

[9] Yusuf Sholihan. Tingkat Pengetahuan Tentang Antibiotik pada Pengunjung Apotek di Kecamatan Jebres. 2015. hal: 1.

[10] Fatmawati I. Tinjauan Pengetahuan, Sikap, dan Perilaku Penggunaan Antibiotik pada Mahasiswa Kesehatan dan Non Kesehatan di Universitas Muhammadiyah Surakarta. 2014.

[11] Theodorus Garry Putra Gan. Hubungan Pengetahuan Tentang Antibiotik tanpa resep di Kalangan Mahasiswa Ilmu Kesehatan Universitas Respati Yogyakarta. 2017.

[12] Yarza HL dkk. Hubungan Tingkat Pengetahuan dan Sikap dengan Penggunaan Antibiotik Tanpa Resep Dokter. Kesehat Andalas. 2015;1(4).hal:6-151.

[13] Widayatun TR. Ilmu Prilaku. Jakarta: CV. Sagung Seto; 2009.hal:133-136.

[14] A W, M D. Teori \& Pengukuran Pengetahuan, Sikap, Dan Perilaku Manusia. Yogyakarta: Nuha Medika; 2019.hal:41-44

[15] Soekidjo Notoatmodjo. Ilmu Perilaku Kesehatan. Jakarta: Rineka Cipta; 2014

Email : heme@unbrah.ac.id 